\title{
KMT2D Gene Mutation
}

National Cancer Institute

\section{Source}

National Cancer Institute. KMT2D Gene Mutation. NCI Thesaurus. Code C150651.

A change in the nucleotide sequence of the KMT2D gene. 